Chantrill, B. H., Coulthard, C. E., Dickinson, L., Inkley, G. W., Morris, W. \& Pyle, A. H. (1952). J. gen. Microbiol. 6, 74,-84

\title{
The Action of Plant Extracts on a Bacteriophage of Pseudomonas pyocyanea and on Influenza A Virus
}

\author{
BY B. H. CHANTRILL, C. E. COULTHARD, LOÏS DICKINSON, \\ G. W. INKLEY, W. MORRIS AND A. H. PYLE
}

The Research Department, Bacteriology Division, Boots Pure Drug Co. Ltd., Nottingham

SUMMARY: Extracts of 288 plants, mostly British, were examined for suppressive action on the development of a bacteriophage of Pseudomonas pyocyanea. Many possessed this property and eight of them suppressed the growth of phage at concentrations less than one-tenth of those which affected the growth of the host, Ps. pyocyanea.

Extracts from 142 of the plants were tested against Influenza A virus in embryonated eggs and twelve of them suppressed virus multiplication. All extracts active against Influenza $A$ virus were also active against the bacteriophage. Four extracts tested against Influenza $A$ in mice were inactive. Eight extracts were investigated further; these were inactivated by proteins and were only active when in direct contact with the virus in protein-free media. Activity was closely associated with the tannin content of the extracts and could not be separated from it. Commercial tannins were also highly active in protein-free media.

During investigations into the chemotherapy of virus diseases a phage of Ps. pyocyanea had been used as a convenient test virus by one of us (Dickinson, 1948) for screening a large number of substances including fifty plant extracts. With certain modifications this work was extended and extracts of 288 plants, mostly British, were investigated. A complete list of the species tested, with their activities, appears in Table 7. The following eight plants were investigated in detail in an attempt to isolate the active principle and elucidate the mode of action: no. 9, Dryopteris filix-mas (Schott); no. 20, Epilobium hirsutum L.; no. 32, Lysimachia Nummularia L.; no. 84, Epilobium angustifolium L.; no. 98, Sedum spurium M. Bieb.; no. 240, Lysimachia vulgaris L.; no. 250, Saxifraga ligulata Wall.; no. 287, Myrica Gale L. (The numbers correspond with those in Table 7.) So far as possible, with British species, names are in accordance with the nineteenth edition (1948) of Hayward's Botanist's Pocket Book.

At some stages of our work the identification of the samples was unable to keep up with the rate of supply, and although a portion of the plants was always kept for examination it was not always possible to decide upon the specific name. Difficulty also arose when an extract from a florist's variety was under test. In both these cases the generic name followed by (?sp.) appears in Table 7. In some cases several varieties of the same species were tested.

\section{METHODS \\ Preparation of extracts}

Plants in as fresh a condition as possible were macerated in distilled water plus $15 \%(\mathrm{v} / \mathrm{v})$ industrial spirit, using a bench macerator with high-speed 
blades, to make $10 \%(\mathrm{w} / \mathrm{v})$ suspensions. The alcohol was used as a preservative, $15 \%$ being the maximum concentration which did not interfere with the tests; bacterial growth was inhibited but moulds occasionally grew on storage. The extracts were usually tested the day after preparation. As far as possible, samples representative of the whole plants were taken, as the concentration of active material in the different parts varied. There was also some variation between samples of the same plant when collected at different times.

\section{Testing of extracts}

Against Ps. pyocyanea phage in vitro. The method was that of Dickinson (1948) with certain modifications. Dilutions of the extracts were made in $9 \mathrm{ml}$. lactate medium, $0.5 \mathrm{ml}$. 1/10 dilution of a $24 \mathrm{hr}$. culture of Ps. pyocyanea (C10) was added, followed at once by $0.5 \mathrm{ml}$. phage $(\mathrm{Pb})$ suspension with a titre of about 7000 infective phage particles per $\mathrm{ml}$. The tubes were incubated at $37^{\circ}$ for $20 \mathrm{hr}$. and a loopful from each was then placed on a seeded plate prepared by pouring a thin layer of agar containing $5 \%(\mathrm{v} / \mathrm{v}) \mathrm{C} 10$ culture on to a layer of nutrient agar and then drying. About thirty-seven 'spots' were placed on each plate. The plates were incubated for $20 \mathrm{hr}$. and then examined. When no bacteriophage suppression occurred in the dilution tubes, the 'spotted' area showed confluent lysis and such dilutions were described as inactive. Dilutions were described as active when no such lysed area formed, provided that the growth of host at that dilution was not affected. The original concentration of phage in the dilutions was insufficient to produce an area of lysis on the plate. Host growth in the dilution tubes was occasionally difficult to estimate due to the presence of the plant debris; usually the formation of a surface pellicle was used as the criterion of host growth but when no pellicle formed, bacterial counts were made by the plate method.

Against Influenza A virus in eggs. Extract $(0 \cdot 2 \mathrm{ml}$.) was inoculated into the allantoic sac of 11-day chick embryos; $1 \mathrm{hr}$. later, approximately $100 \mathrm{minimal}$ infective doses of Influenza A virus (strain PR 8) in $\mathbf{0 . 2}$ ml. phosphate buffer (pH 7.4) were inoculated by the same route, followed by $100 \mathrm{u}$. each penicillin and streptomycin in $0.1 \mathrm{ml}$. water. After a further $48 \mathrm{hr}$. incubation at $37^{\circ}$, the increase of virus in the allantoic sac was detected by the haemagglutination of fowl red blood cells, based on Salk's method (1944). One drop of allantoic fluid was added to $0.5 \mathrm{ml} .0 .25 \%$ washed fowl cells in saline, and the mixture allowed to stand at room temperature for $1 \mathrm{hr}$. Haemagglutination was considered an indication of virus multiplication, as the inoculum was insufficient to cause haemagglutination; neither false haemagglutination nor 'haemagglutination inhibition' was observed in control tests with extracts at the concentrations used. Extracts were also inoculated at varying intervals after infection and via the yolk sac $1 \mathrm{hr}$. before infection.

Against Influenza A virus in mice. The maximum tolerated dose of extract (containing about 10 times the amount found active in the embryonated-egg test) was given subcutaneously twice daily, beginning immediately before infection. Ten to one hundred infective doses of Influenza A virus were given intranasally under light ether anaesthesia. The survivors were killed 7 days 
after infection and the lungs examined. In one test a $1 \%$ solution of an extracted solid was given as an aerosol for $1 \mathrm{hr}$. a day, starting before infection.

\section{EXPERIMENTAL}

Of the 288 extracts 146 were inactive by the phage test and were not investigated further; 142 were examined both by the phage test and the Influenza A test and of these, forty-four were inactive by both tests; ninety-nine showed activity, usually slight, against phage and twelve were active against Influenza A. Of these twelve, eight had a titre of $\mathbf{1 0}$ or more (titres are the reciprocals of the dilutions), when tested against phage (Table 1 ).

Table 1. Effect of plant extracts on the growth of viruses

\begin{tabular}{|c|c|c|c|c|}
\hline \multirow{3}{*}{$\begin{array}{r}\text { Ref. } \\
\text { no. } \\
95\end{array}$} & \multirow{3}{*}{$\begin{array}{c}\text { Name } \\
\text { Potentilla Anserina L. }\end{array}$} & \multicolumn{2}{|c|}{$\begin{array}{l}\text { Ps. pyocyanea phage. } \\
\text { Inhibitory titres }\end{array}$} & \multirow{3}{*}{$\begin{array}{c}\text { Influenza } A \\
\text { virus. } \\
\text { Inhibitory } \\
\text { titres when } \\
\text { injected } 1 \mathrm{hr} \text {. } \\
\text { before } \\
\text { infection } \\
1\end{array}$} \\
\hline & & For host & For phage & \\
\hline & & $<5$ & 5 & \\
\hline 250 & Saxifraga ligulata Wall. (*) & 50 & 450 & $\mathbf{5}$ \\
\hline 98 & Sedium spurium M. Bieb. & 10 & 150 & 1 \\
\hline 84 & Epilobium angustifolium $\mathrm{L}$. & $<5$ & $\mathbf{5}$ & 1 \\
\hline 20 & E. hirsutum L. & $<\mathbf{5}$ & $\mathbf{5}$ & 1 \\
\hline 218 & Fuchsia (hardy garden) & $? 5$ & 10 & $\mathbf{1}$ \\
\hline 32 & Lysimachia Nummularia L. & $<5$ & 100 & $\mathbf{1}$ \\
\hline $\mathbf{2 4 0}$ & L. vulgaris $\mathbf{L} .(\dagger)$ & $<5$ & 100 & 1 \\
\hline 43 & Polygonum amphibium L. & $<5$ & $\mathbf{5}$ & 1 \\
\hline 144 & Rumex (? sp.) & $\mathbf{5}$ & 10 & $\mathbf{1}$ \\
\hline 287 & Myrica Gale L. & 10 & 30 & $\begin{array}{l}\text { Toxic 1; } \\
\text { Inactive } 2\end{array}$ \\
\hline 276 & Scilla nutans $(\ddagger)$ & $<5$ & $\mathbf{5}$ & $\mathbf{1}$ \\
\hline 9 & Dryopteris Filix-mas (Schott) & $<10$ & 100 & 1 \\
\hline
\end{tabular}

${ }^{*}$ ) All garden varieties of the Megasea section of Saxifraga tested, labelled Saxifraga cordifolia, $S$. crassifolia, etc., were active.

$(\dagger)$ Good activity was shown by wild and garden plants. The wild plant appeared to be rather better than the garden ones; the best of the latter we examined was supplied to us as 'var. aurea'.

( $\ddagger$ A garden variety supplied under this name.

Two plants were examined to ascertain distribution of the active material throughout the plant. In the case of Epilobium angustifolium (84), tested against Influenza $\mathbf{A}$ virus in eggs, the higher titres were obtained with extracts from fruits, flowers and leaves, in that order; the stems were inactive. In the case of Saxifraga ligulata (250), tested against phage, the highest activity was obtained with extracts from the rhizome, but this distribution may have been due to the material having been collected in autumn.

Where one plant yielded an active extract there was a tendency for related plants to do so. The best example of this is in the Onagraceae where two species of Epilobium and one of Fuchsia showed activity in both tests; Circaealutetiana and Oenothera biennis also showed activity in the phage test, as did Singhara 
seeds. In the Primulaceae marked activity was shown by Lysimachia Nummularia and $L$. vulgaris in both tests and $L$. nemorum was active against phage. All the common garden Saxifrages of the Megasea type which were examined were highly active.

\section{Preparation of active solids}

Plant no. 250 was macerated in distilled water containing $15 \%$ industrial spirit to make $10 \%(\mathrm{w} / \mathrm{v})$ suspensions. For convenience this preparation was left overnight and the plant debris removed by filtration through kieselguhr. The brown filtrate was adjusted to $\mathrm{pH} \mathrm{2.5}$ with $\mathrm{HCl}$ and then well agitated with $1 \%(\mathrm{w} / \mathrm{v})$ activated carbon. The carbon cake after vacuum filtration was drained and stirred with 10 times its weight of acetone containing $20 \%$ water for $20 \mathrm{~min}$., the carbon filtered off and the acetone eluate shaken with an equal volume of carbon tetrachloride. The activity concentrated in the aqueous phase from which solid material was obtained by evaporation in vacuo at $45^{\circ}$. This process yielded solid material from nos. 9, 20, 84 and 250, but not from nos. 32, 98, 240 and 287. In the case of those plants which did not yield an active solid, the active material appeared to have been absorbed on to the carbon but was not removed by the acetone elution. Solutions of the solids are referred to as 'concentrates' and preparations made in the course of the extraction are termed 'fractions'.

\section{Investigation of active materials}

Phage tests in the presence of protein. When tests were carried out in nutrient broth or in lactate medium containing $10 \%$ serum, all extracts and concentrates were inactive. The results obtained with the solids appear in Table 2.

Table 2. Results of extraction process on active substances

\begin{tabular}{|c|c|c|c|c|}
\hline \multirow{2}{*}{$\begin{array}{l}\text { Ref. } \\
\text { no. }\end{array}$} & \multirow[b]{2}{*}{ Description of solid obtained } & \multirow{2}{*}{$\begin{array}{c}\text { Yield } \\
\text { (g./100 g. } \\
\text { fresh } \\
\text { plant) }\end{array}$} & \multicolumn{2}{|c|}{ Phage titres } \\
\hline & & & In lactate & In broth \\
\hline 9 & Dry, light brown amorphous powder & $0 \cdot 43$ & 30,000 & $<10$ \\
\hline 84 & Dark brown, gummy & $0 \cdot 67$ & $<10$ & - \\
\hline 240 & None & - & - & - \\
\hline 20 & Dark brown, gummy & 0.54 & 300 & $<10$ \\
\hline 93 & None & - & - & 一 \\
\hline 32 & None & - & - & - \\
\hline $\mathbf{2 5 0}$ & Buff, amorphous powder & 0.72 & 50,000 & $<10$ \\
\hline $\mathbf{2 8 7}$ & $\begin{array}{l}\text { Very small yield of dark brown, gummy } \\
\text { material }\end{array}$ & - & - & - \\
\hline $\begin{array}{l}\text { Malabar } \\
\text { kino }\end{array}$ & Dark, reddish brown powder & $6 \cdot 70$ & 100,000 & $<10$ \\
\hline $\begin{array}{l}\text { Tannic } \\
\text { acid }\end{array}$ & Untreated B.P. material & 一 & 10,000 & $<200$ \\
\hline
\end{tabular}

Effect of broth and serum on the action against Influenza $A$ virus. The extracts or concentrates were diluted in broth or $10 \%$ serum before inoculation into the egg. When precipitation occurred the supernatants after centrifugation were used. Substances so treated were inactive. 
T'ests in egg. Extracts which were active when given $1 \mathrm{hr}$. before infection were also active when given $1 \mathrm{hr}$. after infection. In one experiment with no. 84, activity was demonstrated when given $4 \mathrm{hr}$. but not $5 \mathrm{hr}$. after infection. The extracts were inactive when given via the yolk sac.

Tests in vivo. The extracts were inactive against influenza $\mathbf{A}$ virus in mice (Table 3).

Table 3. Action of plant extracts against Influenza $A$ virus in mice

\begin{tabular}{clcl} 
Test & Test material & $\begin{array}{c}\text { Survivors/total } \\
\text { 7th day }\end{array}$ & \multicolumn{1}{c}{ Remarks } \\
1 & No. 84 (extract) & $1 / 9$ & Toxic dose. All lungs infected \\
& Controls & $5 / 10$ & All lungs infected \\
2 & No. 250 fraction & $4 / 10$ & All lungs infected \\
& No. 240 fraction & $5 / 10$ & All lungs infected \\
& Controls & $4 / 10$ & All lungs infected \\
3 & Malabar kino con- & $7 / 11$ & All lungs infected \\
& centrate (1 \% aerosol) & $4 / 8$ & All lungs infected
\end{tabular}

Phage contact test. Solutions ( $1 \%$ ) of the active solids from extracts 240 and 250 and crude extracts of $84,98,240$ and 287 were serially diluted in broth and lactate medium. Volumes $(0.5 \mathrm{ml}$.) of dilutions were left in contact with $0.5 \mathrm{ml}$. phage preparations of known titre for $30 \mathrm{~min}$. at room temperature. After this time, $0.5 \mathrm{ml}$. host culture in nutrient broth plus $4 \mathrm{ml}$. nutrient agar were added. This stopped further action on the phage in lactate medium. The tubes were 'sloped' and incubated for $24 \mathrm{hr}$., when control tubes showed a countable number of plaques.

The phage of Ps. pyocyanea was used in early tests but later the T5 phage of Escherichia coli was used as it proved more sensitive and gave more clear cut results. Extracts of nos. 84 and 250 were tested against both Esch. coli and Ps. pyocyanea phages as well as against their hosts. For host counts, the drug dilutions were mixed with the host, allowed to stand for $1 \mathrm{hr}$., and then 'sloped' with nutrient agar. The inocula were adjusted to give discrete colonies in the control tubes.

The results given in Table 4 indicate that the extracts and concentrates inactivated the phages of Ps. pyocyanea and Esch. coli in defined simple medium when left in contact with them for $30 \mathrm{~min}$. at room temperature, but they did not do so in the presence of broth.

Properties of the active solids. Solutions of the active extracted solids were precipitated by protein media, lead acetate or phenazone (1-phenyl-2,3dimethyl-5-pyrazolone) and gave a blue coloration with ferric chloride. Similar tests to those described for the tests in eggs were carried out with extracts which had been treated with varying concentrations of phenazone to precipitate tannins. Concentrations ranged from 1 to $12 \%$ phenazone, and after standing for $1 \mathrm{hr}$. at room temperature the tubes containing the maximum precipitate (usually about $3 \%$ phenazone), were centrifuged at 10,000 r.p.m. for $15 \mathrm{~min}$. Supernatants and precipitates were tested separately 
Table 4. Contact tests against bacteria and phage

\begin{tabular}{llrrrr} 
& & \multicolumn{4}{c}{ Titres* } \\
\cline { 3 - 5 } Test material & Medium & $\begin{array}{c}\text { Ps. } \\
\text { pyocyanea } \\
\text { host }\end{array}$ & $\begin{array}{c}\text { Ps. } \\
\text { pyocyanea } \\
\text { phage }\end{array}$ & $\begin{array}{c}\text { Esch. } \\
\text { coli } \\
\text { host }\end{array}$ & $\begin{array}{c}\text { T5 } \\
\text { phage }\end{array}$ \\
No. 250 extract & Lactate & 16 & 64 & 64 & 1024 \\
No. 250 solid (1 \% & Broth & 16 & 0 & 64 & 4 \\
solution) & Bactate & 16 & \pm 64 & 4 & 64 \\
No. 84 extract & Lactate & 16 & 0 & 4 & 0 \\
Malabar kino solid & Broth & 16 & \pm 4 & 2 & 16 \\
(1 \% solution) & Lactate & 0 & 0 & 2 & 0 \\
& Broth & 0 & 16 & 0 & 16
\end{tabular}

* Titre is the reciprocal of the dilution necessary to decrease the count of the test organism to $<10 /$ tube.

in lactate medium and in broth. The results in Table 5 show that when precipitation occurred, the supernatant had little or no activity. The phenazone precipitates showed slight activity, probably due to dissociation of the complex.

Table 5. Action of phenazone on plant extracts in contact tests

\begin{tabular}{|c|c|c|c|c|c|}
\hline \multirow[b]{2}{*}{ Test material } & \multirow[b]{2}{*}{ Medium } & \multicolumn{3}{|c|}{ Titre against $\mathrm{T} 5$ phage } & \multirow[b]{2}{*}{ Remarks } \\
\hline & & Extract & $\begin{array}{c}\text { Super. } \\
\text { after } 1-3 \% \\
\text { phenazone }\end{array}$ & $\begin{array}{l}\text { Ppt. made } \\
\text { up to } \\
\text { volume }\end{array}$ & \\
\hline No. 98 extract & $\begin{array}{l}\text { Lactate } \\
\text { Broth }\end{array}$ & $\begin{array}{l}8 \\
0\end{array}$ & $\begin{array}{l}4 \\
0\end{array}$ & $\begin{array}{l}\mathbf{2} \\
\mathbf{0}\end{array}$ & Only slight ppt. \\
\hline No. 240 extract & $\begin{array}{l}\text { Lactate } \\
\text { Broth }\end{array}$ & $\begin{array}{r}32 \\
2\end{array}$ & $\begin{array}{l}4 \\
0\end{array}$ & $\begin{array}{r}32 \\
0\end{array}$ & Heavy ppt. \\
\hline No. 287 extract & $\begin{array}{l}\text { Lactate } \\
\text { Broth }\end{array}$ & $\begin{array}{r}32 \\
2\end{array}$ & $\begin{array}{l}\mathbf{2} \\
\mathbf{2}\end{array}$ & $\begin{array}{r} \pm 10 \\
0\end{array}$ & Variable ppt. \\
\hline No. 84 extract & $\begin{array}{l}\text { Lactate } \\
\text { Broth }\end{array}$ & $\begin{array}{r}16 \\
0\end{array}$ & $\begin{array}{l}\mathbf{0} \\
\mathbf{0}\end{array}$ & $\begin{array}{l}8 \\
0\end{array}$ & Heavy ppt. \\
\hline $\begin{array}{l}\text { Malabar kino solid } \\
\text { (1 \% solution) }\end{array}$ & $\begin{array}{l}\text { Lactate } \\
\text { Broth }\end{array}$ & $\begin{array}{r}100 \\
5\end{array}$ & $\begin{array}{l}\mathbf{0} \\
\mathbf{0}\end{array}$ & $\begin{array}{l}\mathbf{2} \\
\mathbf{0}\end{array}$ & Heavy ppt. \\
\hline
\end{tabular}

\section{Investigation of the tannins}

In view of the properties, source and mode of extraction of the active solids, it was suggested that the activity was due to tannins. Several samples of commercial tannins were therefore investigated in both lactate medium and broth and against Influenza $A$ virus (Table 6). All extracts were inactive against phage in broth. Malabar kino was extracted by the same method as the plants and yielded a very potent solid; this was also inactive in broth. The malabar kino concentrate was inactive in vivo. It behaved similarly to the plant extracts when tested in a contact test against Ps. pyocyanea and Esch. coli, phages before and after phenazone treatment. 
Table 6. Effect of extracts of pharmaceutical tannin-containing drugs on the growth of viruses

Sample (tested as
a $1 \cdot 0 \%$ (w/v) maceration
in $15 \%$ ethanol)
Hammamelis leaves
Caryophyllum (cloves)
Gallum (oak galls)
Cinnamon bark
Oak bark
Mate Tea leaves
Cinchona bark
Malabar kino
Eucalyptus kino
Catechu
Krameria root
Areca nut
Catechu nigrum
Bengal kino

\begin{tabular}{|c|}
\hline $\begin{array}{l}\text { Ps. pyocyanea } \\
\text { bacteriophage; } \\
\text { (titre in } \\
\text { lactate medium) }\end{array}$ \\
\hline 100 \\
\hline 50 \\
\hline 300 \\
\hline $\mathbf{3 0}$ \\
\hline 80 \\
\hline 50 \\
\hline 50 \\
\hline 300 \\
\hline 300 \\
\hline 100 \\
\hline 300 \\
\hline 500 \\
\hline 100 \\
\hline 1,000 \\
\hline
\end{tabular}

Influenza A (titre in eggs)

1
1
$n t$
1
1

Inactive 10, toxic 1 1

Active 10, toxic 1 nt 1

Active 10, toxic 1 10

Active 10, toxic 1

1

nt $=$ not tested.

\section{DISCUSSION}

The complete lack of action of the plant extracts in the presence of serum or broth, the effect of phenazone treatment and the properties of the active solids suggested that all the plant extracts investigated owed their activity to their tannin content. This view was supported by the similar behaviour of commercial tannins. Although extracts of different plants did not always behave alike, e.g. in their adsorption to and elution from carbon, this phenomenon is not unexpected, 'tannins' being a descriptive term for different chemical substances. The possibility that the active material was not itself a tannin, but was carried down by the precipitates was not excluded but, in view of the behaviour of commercial tannins, this seems unlikely.

Since the plant extracts were active against phage only in protein-free medium it seemed unlikely that they would be of chemotherapeutic value; the small-scale mouse test against Influenza A virus supported this view. The action of the extracts on Influenza $\mathbf{A}$ virus in eggs is of interest and, early in the work, resulted in false assumptions being made as to the mode of action. The extracts were active when given $1 \mathrm{hr}$. before and $1 \mathrm{hr}$. after infection, and in one experiment extract no. 84 was active $4 \mathrm{hr}$. but not $5 \mathrm{hr}$. after infection. It was at first thought that this indicated an interference with the metabolism of virus within the host cells, but it is now evident that a viricidal action in the allantoic fluid, which contains very little protein, cannot be excluded. After $1 \mathrm{hr}$. and certainly after $4 \mathrm{hr}$. the virus would have been adsorbed on to the cells but the extracts could still exert their viricidal action when the virus was liberated into the allantoic fluid. Broth and serum-treated extracts were inactive against Influenza $A$ when given via the allantoic sac, and the extracts showed no activity when given via the yolk sac. Similar results have been reported by Green (1948), who found that tannic acid prevented the multi- 
plication of Influenza A virus in the allantoic sac when given up to $6 \mathrm{hr}$. after infection; the virus was inactivated in vitro. Green (1949) also found that tea extracts were active via allantoic sac $2 \mathrm{hr}$. after infection but were inactive via the yolk sac. One of the incidental aims of these investigations was to establish a correlation, if any, between the phage test and the Influenza $A$ test. Since the active principles of all the plants were probably acting by a similar mechanism, due to their tannin properties, the results do not clarify the position. However, no extract was found to be active against Influenza A without also showing activity against phage. The reverse was not true, 87 extracts showing slight activity against phage and none against Influenza $A$. It should be noted that in the phage test solutions are diluted $1 / 5$, whereas in the egg test they are diluted about $1 / 50$ by the allantoic fluid. In the absence of certain correlation, phage can only be used as one convenient test virus for 'screening' purposes. The results may or may not be applicable to other viruses.

Table 7. List of plants (with laboratory reference numbers in italic) tested against phage. Titre, in brackets, is the reciprocal of the dilution at which the extract was active. Extracts when tested against Influenza virus $A$ in eggs are shown when active as $V+$, or when inactive as $V-$

Alismaceae. 5, Alisma Plantago-aquaticum L. (5) V - ; 255, Sagittaria sagittifolia L. (0).

Apocynaceae. 225, Vinca major L. (5).

Araceae. 242, Acorus calamus L. (0).

AramiaceaE. 171, Hedera helix L. (0).

Auriculariaceae. 284, Auricularia mesenterica Bull (0).

Berberidaceae. 220, Berberis stenophylla (5) V-;217, B. subcauliata (15) V-; 12, B. vulgaris L. (0) V - ; 228, Mahonia aquifolium Pursh. (0).

Boraginaceae. 289, Myosotis sp. (5); 96, Pulmonaria officinalis L. (0) V-.

Campanulaceae. 111, Campanula portenschlagiana $(5) ; 175$, C. rotundifolia $\mathrm{L}$. (0).

Cannabinaceae. 259, Humulus lupulus L. (0).

CaPrifoliaceae. 210, Lonicera nitida Wilson (0); 252, Symphoricarpus racemosus (0); 169 , Viburnum opulus L. (0); 215, V.tinus (0) V-; 219, Weigelia rosea Lindley (0).

Caryopayllaceae. 192, Dianthus barbatus (5) V-; 189, D. Caryophyllus L. (5) V-; 193, D. plumarius L. (5) V-;267, Dianthus sp. (single, garden variety) (5); 141, Lychnis alba Mill. (0); 131, Sagina procumbens L. (5) V-; 55, Silene maritima With. (0) V-; 57, Spergularia marina (0) V-.

Chenopodiaceae. 110, Atriplex patula L. (5) V-;11, A. portulacoides L. (0) V - ; 279, Beta (sugar beet) (0); 280, Chenopodium fruit (pharmaceutical) (5); 81, Chenopodium sp. (5) V - ; 48, Salicornia herbacea (0) V - ; 65, Suaeda fruticosa Forsh. (0); 64, S. maritima Dum. (5) $\mathrm{V}$ - .

Commelinaceas. 104, Tradescantia virginica $(0) \mathrm{V}$ - .

Compositae. 2, Achillea Millefolium L. (5) V-; 1, A. Ptarmica L. (0) V-; 160, Anthemis Cotula L. (0); 73, Arctium Lappa L. (5) V-; 74, Artemisia Absinthium L. (5) V-; 75, A. vulgaris L. (0) V-; 10, Aster maritima (0) V-;294, Bellis perennis L. (5); 203 , Bidens cernua L. (5); 138, Buphthalmium sp. (garden variety) (5); 180, Callistephus sinensis (5); 191, Centaurea Cyanus L. (5); 15, C. nigra L. (5) V- ; 140, Chrysanthemum Parthenium Bernh. (0); 79, Cirsium arvense Scop. (5); 80, C. eriophorum Scop. (5) V - ; 139, C. lanceolatum Scop. (5); 162, C. palustre Scop. (5); 115, Crepis virens L. (5) V - ; 184, Cosmos bipinnatus (5); 159, Erigeron canadensis L. (5); 233, Eupatorium cannabinum L. (5); 178 Galinsoga parviflora Cav. (5); 188, Hieracium Pilosella L. (0) V- ; 28, Hypochaeris radicata L. (0) V - ; 226, Lactuca muralis Fres. (5); 123, Lapsana communis L. (0); 149, Leontodon autumnalis L. (5); 33, Matricaria inodora L. (0) V-;34, M. suaveolens Buch. (0) V-; 148, Leontodon hispidus L. (0); 264, Petasites fragrans Presl. (0); 170, Picris Echioides L. (5); 46, Pulicaria dysenterica Gray (5) V-; 52, 


\section{Table 7 (cont.)}

Senecio aquaticus Hill (?); 53, S. Jacobaea L. (5) V-;97, S. squalidus L. (0) V - ; 132, S. vulgaris L. (5) V-;16\%, Sonchus asper Hill (5); 100, S. arvensis L. (5) V-; 153, S. oleraceus L. (0); 179, Tagetes signata (5); 67, Tanacetum vulgare L. (0) V - ; 147, Taraxacum officinale W. (5); 103, Tragopogon pratensis L. (5) V-; 195, Tussilago Farfara L. (0).

Convolvulaceae. 223, Calystegia sepium Br. (5); 145, Convolvulus arvensis L. (0).

Cornaceae. 190, Cornus sanguinea L. (10) V-.

Crassulaceas. 271, Sedum sarmentosum (10) V-;266, S. spectabile (0); 98, S. spurium M. Bieb. (150) $\mathrm{V}+$.

Cruciferae. 290, Arabis albida (5); 112, Capsella bursa-pastoris Med.(5) V - ; 260, Cochlearia Armoracia L. (0); 293, Iberis sempervirens (?); 172, Lepidium ruderale L. (0); 229, Lunaria biennis (0); 185, Matthiola sp. (garden variety) (5); 254. Raphanus Raphanistrum L. (0); 152 Sisymbrium altissimum L. (5); 133, S. officinale Scop. (0).

Cucurbitaceae. 137, Bryonia dioica Jacq. (0).

Cupressaceae. 216, Chamaecyparis nootkatensis Lambert (5) V -

Dioscoreaceae. 66, Tamus communis L. (5) V-.

DipsaCaCeae. 83, Dipsacus sylvestris Huds. (5); 187, Scabiosa arvensis L. (0) V - ; 50, S. Succisa L. (0) V - .

EquISETUM. 86, Equisetum sp. (5) V-.

Ericaceae. 238, Calluna vulgaris Hull. (10).

Euphorbiaceae. 224, Buxus sempervirens L. (5); 119, Euphorbia Helioscopia L. (0); 120, E. Peplus L. (0); 239, Euphorbia sp. (5).

Fumariaceae. 117, Dielytra eximia (0).

Geraniaceae. 23, Geranium pratense L. (0) V-; 244, Impatiens glandulifera Royle (0).

Graminaceae. 6, Alopeeurus pratensis L. (0); 107, Agropyron repens Beauv. (5) V-; 158, Agrostis sp. (5) V - ; 109, Arrhenatherum avenaceum Beauv. (5) V - ; 13, Brachypodium pinnatum Beauv. (?) V-; 43, Dactylis glomerata L. (5) V +; 19, Deschampsia caespitosa Beauv. (5) V - ; 25, Glyceria aquatica Wahl. (5) V - ; 157, Holcus lanatus L. (5) V - ; 122, Hordeum murinum L. (5); 126, Lolium perenne L. (0); 199, Phalaris arundinacea L. (0); 165, Phleum (? praecox) (0); 39, P. pratense L. (0) V - ; 213, Poa sp. (0).

Gentianaceat. 85, Erythraea Centaurium Druce (5) V-; 232, Gentiana Amarella L. (5).

Haloragaceae. 247, Hippuris vulgaris L. (0).

HYPERICACEAE. 207, Hypericum Androsaemum L. (0) V - ; 27, H. perforatum L. (5) V - .

IRIDACEAE. 127, Montbretia sp. (garden variety) (0).

LaBiateae. 151, Ballota nigra L. (0); 14, Clinopodium vulgare L. (5) V- ; 21, Galeopsis Tetrahit L. (0) V - ; 90, Lamium album L. (5) V - ; 124, Lavandula officinalis Chaix. (0); 35, Melissa officinalis L. (0) V-; $36 a$, Mentha sp. (0) V-; $36 b$, M. aquatica L. (5) V-; 45, Prunella vulgaris L. (5) V - ; 51, Scutellaria galericulata L. (0) V - ; 60, Stachys officinalis Fr. (5) V - ; 61, S. sylvatica L. (0) V - ; 68, Teucrium Scorodonia L. (5) V - ; 102, Thymus sp. (garden lemon thyme) (5) V-; 292, T. serpyllum L. (5).

Leguminoseae. 91, Lotus corniculatus L. (5) V - ; 234, Medicago sativa L. (5); 92, Melilotus officinalis Lam. (0) V-; 168, Ononis arvensis L. (0); 246, Robinia hispida L. (0); 288 , Robinia pseudacacia L. (10); 155, Trifolium repens L. (0); 164, Trifolium sp. (5); 245, Ulex europceus L. (5); 72, Vicia Cracca L. (5) V-; 106, Wistaria sinensis Sweet. (5) V-.

Liliaceas. 135, Allium oleraceum L. (0); 76, Asparagus officinalis L. (0); 114, Convallaria majalis L. (5) V-; 129, Polygonatum sp. (garden variety). (0); 276, Scilla nutans (garden variety) (5) $\mathrm{V}+$.

LiNACEaE. 237, Linum catharticum L. (0) V - .

LOganiaCEAE. 201, Buddleia sp. (0).

LyThraceae. 230, Lythrum Salicaria L. (0).

MaLvaCEAE. 183, Althea rosea (0); 222, Hibiscus syriacus L. (0) V- ; 142, Malva sylvestris L. (5).

MYricaceae. 287, Myrica Gale L. (30).

Nymphaceat. 243, Nymphaea lutea L. (0).

Oleaceae. 214, Forsythia sp. (0); 209, Jasminum nudiflorum Lindley (0) V - ; 163, Ligustrum vulgare L. (0). 
Onagraceate. 194, Clarkia pulchella (0); 113, Circaea lutetiana L. (5) V - ; 84, Epilobium angustifolium L. (5) V + ; 20, E. hirsutum L. (5) V+; 257, E. parviflorum Schreb. (5); 218, Fuchsia sp. (hardy garden variety) (10) V+; 262, Oenothera biennis L. (5) V-; $27 \%$, Singhara seeds (5) V-.

Oxalidaceae. 38 , Oxalis Acetosella L. (0) V-.

Papaveraceae. 205, Chelidonium majus L. (5); 24, Glaucium flavum Cr. (0) V - ; 227, Papaver Rhoeas L. (5); 154, P. somniferum L. (0).

Prnaceat. 263, Cedrus atlantica Manetti (0).

Plantaginaceae. 40, Plantago media L. (5) V-.

Plumbaginaceae. 261, Ceratiostigma sp. (0); 241, Statice sp. (annual garden variety) (5); 272, S. maritima Mill. (15) V-;274, S. armeria (large leaved garden) (5) V - ; 63, S. Limonium L. (5); 62, Statice sp. (perennial garden) (5) V-.

Polygonaceae. 283, Buckwheat seed (of commerce) (5); 43, Polygonum amphibium L. (5) V + ; 94, P. aviculare L. (5) V - ; 221, P. cuspidatum (10) V - ; 231, P. Hydropiper L. (5); 235, P. Persicaria L. (0); 130, Rumex acetosella L. (0) V-; 144, Rumex sp. (10) $\mathrm{V}$-; 282, Rhubarb root (of commerce). (50).

Polypodiaceae. 9, Dryopteris Filix-mas Schott. (100) V+.

Polyporaceae. 136, Boletus sp. (0); 173, Polystictus versicolor (5); 174, Daedalea quercina P. (0).

Primulaceae. 7, Anagallis arvensis L. (0) V-; 31, Lysimachia nemorum L. (10) V-; 32, L. Nummularia L. (100) V + ; 240, L. vulgaris L. (100) V +.

Punicaceae. 281, Punica granatum (Root bark of commerce) (0).

Ranunculaceae. 108, Anemone japonica (5) V-;47, Ranunculus sceleratus L. (0) V-; 101, Thalictrum minus L. (5) V-.

Resedaceae. 258, Reseda Luteola L. (0); 181, R. odorata (0).

Rosaceae. 3, Agrimonia Eupatoria L. (10) V-;4, Alchemilla vulgaris L. (0) V-; 166, Cretaegus Oxyacantha L. (10); 116, Cydonia sp. (garden variety) (0); 208, Malus sp. (garden variety) (0); 95, Potentilla Anserina L. (5) V+; 186, P. reptans L. (0); 150, Prunus spinosa L. (0); 176, Pyracantha lelandii (10) V-;49, Sanguisorba officinalis L. (0) V - ; 59, Spirea Ulmaria L. (5) V-.

Rubiaceae. 88, Galium Cruciata Scop. (5) V - ; 22, G. verum L. (5) V - .

Salicaceae. 256, Salix fragilis $\mathbf{L}$. (0).

Saxifragaceat. 251, Escallonia langleyense (0); 206, Escallonia sp. (5) V-; 269 , Hydrangea sp. (0) V-;273, Philadelphus sp. (5) V-;250, Saxifraga ligulata Wall. (450) V + ; 270, S. umbrosa L. (5) V-.

Scrophulariaceae. 78 , Bartsia Odonites Huds. (0) V-; 118, Digitalis purpurea L. (0); 87, Euphrasia officinalis L. (5) V-; 125, Linaria minor Desf. (5); 29, L. vulgaris Mill. (5) V - ; 204, Scrophularia aquatica L. (0); 161, S. nodosa L. (0); 71, Veronica Beccabunga L. (0) V - ; 156, Verbascum Thapsus L. (0).

Solanaceae. 89, Hyoscyamus niger L. (5) V-; 30, Lycium chinense Mill (?); 182, Nicotiana tabacum (0); 134, Solanum Dulcamara L. (0); 99, S. lycopersicum. (0) V- ; 236, S. nigrum L. (0).

Thymeleaceae. 249, Daphne Mezereum L. (0).

Tropaeolaceae. 248, Tropaeolum majus (0).

TyPhaceaE. 58, Sparganium ramosum Huds. (5) $\mathrm{V}$ -

Umbelliferae. 8, Angelica sylvestris L. (0) V-; 146, Apium nodiflorum R. f. (0); 16 , Conium maculatum L. (5) V-;18, Daucus carota L. (5); 121, Foeniculum vulgare Mill (0); 26, Heracleum Sphondylium L. (0) V-; 128, Myrrhis Odorata Scop. (0); 37, Oenanthe fistulosa L. (5) V-;93, Pastinaca sativa L. (5) V-;41, Pimpinella major Huds. (0) V - ; 42, P. Saxifraga (5) V - ; 198, Sanicula europaea L. (0) V - ; 54, Silaus flavescens Bernh. (5) V-;56, Sison Amomum L. (5) V-; 70, Torilis anthriscus Gmel. (5) $\mathrm{V}$ -

Urticaceat. 19\%, Parietaria ramiflora Moench. (0); 253, Urtica dioica L. (0).

VIOLACEAE. 105, Viola odorata L. (?) V - ; 212, V. tricolor L. (?) V-.

Thanks are due to Sir Jack Drummond, F.R.S., for his interest in this work and to Miss J. Sudworth for technical assistance. We are indebted to a number of workers, particularly Miss E. M. Gregory, for help in the collection of plants and to Dr R. Michaelis for extraction of the tannins. 


\section{REFERENCES}

Dickinson, L. (1948). The bacteriophages of Ps. Pyocyanea. 1. The effect of various substances upon their development. J. gen. Microbiol. $2,154$.

Green, R. H. (1948). Inhibition of Influenza virus by tannic acid. Proc. Soc. exp. Biol., N.Y., 67, 483.

Green, R. H. (1949). Inhibition of multiplication of Influenza virus by extracts of tea. Proc. Soc. exp. Biol., N.Y., 71, 84.

SALK, J. E. (1944). A simplified procedure for titrating haemagglutinating capacity of Influenza virus and the corresponding antibody. J. Immunol. 49, 87.

(Received 5 July 1951) 